ARTICLE

DOI: $10.1038 / s 41467-018-06967-8$

\title{
Breaking the scaling relationship via thermally stable Pt/Cu single atom alloys for catalytic dehydrogenation
}

Guodong Sun ${ }^{1,2}$, Zhi-Jian Zhao (10) 1,2, Rentao Mu², Shenjun Zha1,2, Lulu Li ${ }^{1,2}$, Sai Chen ${ }^{1,2}$, Ketao Zang ${ }^{3}$, Jun Luo ${ }^{3}$, Zhenglong $\mathrm{Li}^{4}$, Stephen C. Purdy ${ }^{5}$, A. Jeremy Kropf ${ }^{6}$, Jeffrey T. Miller ${ }^{5}$, Liang Zeng ${ }^{1,2}$ \& Jinlong Gong (i) ${ }^{1,2}$

Noble-metal alloys are widely used as heterogeneous catalysts. However, due to the existence of scaling properties of adsorption energies on transition metal surfaces, the enhancement of catalytic activity is frequently accompanied by side reactions leading to a reduction in selectivity for the target product. Herein, we describe an approach to breaking the scaling relationship for propane dehydrogenation, an industrially important reaction, by assembling single atom alloys (SAAs), to achieve simultaneous enhancement of propylene selectivity and propane conversion. We synthesize $\gamma$-alumina-supported platinum/copper SAA catalysts by incipient wetness co-impregnation method with a high copper to platinum ratio. Single platinum atoms dispersed on copper nanoparticles dramatically enhance the desorption of surface-bounded propylene and prohibit its further dehydrogenation, resulting in high propylene selectivity ( 90\%). Unlike previous reported SAA applications at low temperatures $\left(<400^{\circ} \mathrm{C}\right), \mathrm{Pt} / \mathrm{Cu} \mathrm{SAA}$ shows excellent stability of more than $120 \mathrm{~h}$ of operation under atmospheric pressure at $520^{\circ} \mathrm{C}$.

\footnotetext{
${ }^{1}$ Key Laboratory for Green Chemical Technology of Ministry of Education, School of Chemical Engineering \& Technology, Tianjin University, Tianjin 30072, P. R. China. ${ }^{2}$ Collaborative Innovation Center for Chemical Science \& Engineering (Tianjin), Tianjin 30072, P. R. China. ${ }^{3}$ Center for Electron Microscopy, Institute for New Energy Materials and Low-Carbon Technologies, School of Materials, Tianjin University of Technology, Tianjin 300384, P. R. China. ${ }^{4}$ Energy and Transportation Science Division, Oak Ridge National Laboratory, Oak Ridge, TN 37831, USA. ${ }^{5}$ Davidson School of Chemical Engineering, Purdue University, West Lafayette, IN 47907, USA. ${ }^{6}$ Chemical Technology Division, Argonne National Laboratory, Argonne, IL 60439, USA. These authors contributed equally: Guodong Sun, Zhi-Jian Zhao. Correspondence and requests for materials should be addressed to J.G. (email: jlgong@tju.edu.cn)
} 
T he development of new catalysts with simultaneously enhanced activity and selectivity is always the ultimate goal of researchers. In heterogeneous catalysis, the screening of new catalyst can be simply guided by the Sabatier principle. It indicates that the best catalysts should bind reactive intermediates with suitable interaction strength: neither too strong that leads to surface poisoning, nor too weak which fails to activate the reactants ${ }^{1}$. The principle behind this phenomenon can be attributed to the existence of scaling properties of adsorption energies on transition metal surfaces ${ }^{2}$, and various linear scaling relationships have been developed which connect the reaction energy/barriers with binding energy of representative surface species, i.e., descriptors. Therefore, the complicated reaction kinetics can be described by only a few descriptors, which enables fast screening of potential catalytic materials with the help of density functional theory (DFT) calculations ${ }^{3}$.

However, due to the existence of the scaling relationship, the enhancement of the activity toward the aimed product frequently accompanies a series of similar side reactions, leading to the reduced selectivity ${ }^{4}$. Considering the specific case of propane dehydrogenation $(\mathrm{PDH})$, the key industrial reaction for the production of propylene is normally catalyzed by PtM alloys such as $\mathrm{PtSn}^{5}, \mathrm{PtZn}^{6}, \mathrm{PtGa}^{7}, \mathrm{PtIn}^{8}, \mathrm{PtGe}^{9}$, and $\mathrm{PtCu}^{10}$. Our previous DFT calculations indicate that the catalytic properties of these PtM alloys are indeed restricted by the scaling relationship, which normally results in the promoted selectivity to propylene accompanied with the suppressed intrinsic activity for dehydrogenation of propane ${ }^{11}$. Therefore, it is desirable to develop a catalyst that can break the scaling relationship to achieve the improvement of activity and selectivity concurrently ${ }^{12}$.

Single-atom catalysis has become one of the most active new frontiers in heterogeneous catalysis ${ }^{13}$. A large number of singleatom catalysts (SACs) exhibit distinct and often outstanding performances in a broad scope of chemical reactions, such as CO oxidation $^{14,15}$, water-gas shift reaction (WGS $)^{16-18}$, methanol steam reforming $(\mathrm{MSR})^{19,20}$, hydrogen evolution reaction (HER) $)^{21-23}$, hydrogenation of substituted nitroarenes ${ }^{24,25}$, hydrogenation of alkynes and dienes ${ }^{26-29}$, and hydrogenation of carbon dioxide ${ }^{30-32}$. However, SACs do not find broad application in high temperature $\left(>500^{\circ} \mathrm{C}\right)$ light alkane dehydrogenation reactions. Although single-site $\mathrm{Zn}(\mathrm{II})^{33}, \mathrm{Co}(\mathrm{III})^{34}, \mathrm{Ni}(\mathrm{II})^{35}$, and $\mathrm{Ga}(\mathrm{III})^{36}$ on silica have been developed as selective PDH catalysts, these active sites suffer from low activity compared to metallic sites. To the best of our knowledge, high stability and selectivity have not been achieved for the PDH reaction with the use of single-atom Pt catalysts.

Herein, we report that $\mathrm{Pt} / \mathrm{Cu}$ single atom alloy (SAA) breaks the PtM alloy scaling relationship during the PDH, with a great improvement of propylene selectivity and a slight loss of intrinsic dehydrogenation activity. Based on the theoretical analysis, we design and synthesize the catalysts with $\mathrm{Pt} / \mathrm{Cu} \mathrm{SAA}$ supported on $\gamma$-alumina via an atomic dilution method and confirm the formation of Pt/Cu SAA through detailed characterizations, such as CO-diffuse reflectance infrared Fourier-transform spectroscopy (CO-DRIFTS), aberration-corrected high-angle annular darkfield scanning transmission electron microscope (AC-HAADFSTEM) and extended X-ray absorption fine structure (EXAFS) spectra. Subsequent catalytic tests demonstrate the transferability from DFT calculations to practical catalytic reaction and the Pt/ $\mathrm{Cu}$ SAA catalyst with the low loading of Pt $(0.1 \mathrm{wt} \%)$ displays propylene selectivity of $\sim 90 \%$ with the high formation rate of $10.6 \mathrm{~mol} \mathrm{~g}^{-1} \mathrm{Pt}^{-1}$ under the conditions of atmospheric pressure, $520^{\circ} \mathrm{C}$, WHSV $=4 \mathrm{~h}^{-1}, \mathrm{C}_{3} \mathrm{H}_{8} / \mathrm{N}_{2}=1 / 1$. Unlike previous reported low temperature SAA applications ${ }^{26,29,37-39}$, our synthesized $\mathrm{Pt} / \mathrm{Cu}$ SAA shows excellent stability for at least $120 \mathrm{~h}$ on stream at $520^{\circ} \mathrm{C}$.

\section{Results}

Theoretical prediction. Previous studies have shown that the alkane dehydrogenation reaction is insensitive to the structure of the Pt particles, because single atoms of Pt are capable of catalyzing the reaction ${ }^{40}$. However, undesired side reactions that occur during the alkane dehydrogenation, such as hydrogenolysis, isomerization and coke formation, are structure sensitive reactions, requiring more than one $\mathrm{Pt}$ atom ${ }^{41}$. Therefore, isolated $\mathrm{Pt}$ atoms are expected to be a potential active center with high propylene selectivity. It is worth noting that noble metals are active for dehydrogenation in the metallic state ${ }^{41}$. Xiong et al. reported that single Pt atoms on $\mathrm{CeO}_{2}$ can only promote the cleavage of $\mathrm{C}-\mathrm{C}$ bonds of hydrocarbons with no observed selectivity toward dehydrogenation ${ }^{42}$. Therefore, SAAs attract our attention, where the catalytically active metal is atomically dispersed in the surface layer of the more inert host metal and exists in the metallic state, distinguishing from single atoms positively charged on metal oxides ${ }^{26,43}$. Such SAAs have been widely used as a strategy for selective hydrogenation reactions, such as the selective hydrogenation of styrene, acetylene, and 1,3butadiene ${ }^{26,29}$. Recently, Pt/Cu SAAs were suggested as an approach to coke-resistant $\mathrm{C}-\mathrm{H}$ activation chemistry and examined in the systems of methyl groups, methane, butane, and propane ${ }^{37}$. However, no stable SAA under reducing environment at high temperatures $\left(>400^{\circ} \mathrm{C}\right)$ has been reported so far. This raises the question whether SAAs are capable of breaking the restriction of the scaling relationship for PtM alloys and catalyzing dehydrogenation reactions at high temperatures stably.

As shown in previous theoretical studies, the PDH activity can be described by the first dehydrogenation barrier which is the rate-determining step, and the selectivity was estimated by the difference between di- $\sigma$ propene desorption barrier and its further dehydrogenation barrier (the highest barrier for di- $\sigma$ propene dehydrogenation to $\mathrm{C}_{3} \mathrm{H}_{4}$ shown in Fig. 1d and Supplementary Figure 1$)^{11}$. Due to the existence of the scaling relationship for $\mathrm{Pt}_{3} \mathrm{M}(\mathrm{M}=3 \mathrm{~d}$ and $4 \mathrm{~d}$ transition metals), low dehydrogenation barrier (i.e., high PDH activity) accompanies with strong C-Pt interaction, leading to strong propene adsorption (i.e., low propene selectivity) (Fig. 1a). However, isolated Pt atoms dispersed in $\mathrm{Cu}$ nanoparticles maintain a reasonable dehydrogenation activation barrier and at the same time display a quite high selectivity, which is reflected by the low binding strength of propylene and high deep dehydrogenation barrier (Fig. 1a). Our DFT calculations suggest that $\mathrm{Pt} / \mathrm{Cu}$ SAA indeed breaks the PtM alloy scaling relationship, which is different from the scaling for conventional Pt alloys during the PDH (Fig. 1b). Unlike over Pt surfaces, the isolated $\mathrm{Pt}$ atom in $\mathrm{Pt} / \mathrm{Cu}$ SAA can only interact with a single Pt atom for the deep dehydrogenated $\mathrm{C}_{3} \mathrm{H}_{5}$, a model precursor of coke formation, instead of more stable three $\mathrm{Pt}-\mathrm{C}$ interactions on threefold hollow site over Pt(111) (Fig. 1c). The deep dehydrogenation thus becomes strongly endothermic over $\mathrm{Pt} / \mathrm{Cu}$ SAA with a significant free energy barrier $(>2 \mathrm{eV})$, compared with the same step over $\operatorname{Pt}(111)$ with a surmountable barrier $(<1 \mathrm{eV})$, leading to a much higher propylene selectivity over Pt/Cu SAA (Fig. 1d). The binding strength of $\pi$ adsorbed propylene over $\mathrm{Pt} / \mathrm{Cu}$ SAA $(-0.57 \mathrm{eV})$ is also weaker than the di$\sigma$ ones over $\mathrm{Pt}_{3} \mathrm{Cu}(111)(-0.88 \mathrm{eV})$ and $\mathrm{Pt}(111)(-1.10 \mathrm{eV})$, further facilitating propylene desorption over $\mathrm{Pt} / \mathrm{Cu}$ SAA (Supplementary Table 1). However, for the first two dehydrogenation steps, the geometry effects mentioned above are less apparent, due to no binding mode change for propyl over our calculated surfaces. Therefore, the destabilization of dehydrogenated intermediates over $\mathrm{Pt} / \mathrm{Cu}$ SAA is less obvious than $\mathrm{C}_{3} \mathrm{H}_{5}$ (Fig. 1c). This is also important for Pt/Cu SAA to maintain reasonably low dehydrogenation barriers for the first two dehydrogenation steps. Compared with $\mathrm{Pt}(111), \mathrm{Pt} / \mathrm{Cu}$ SAA only 
a

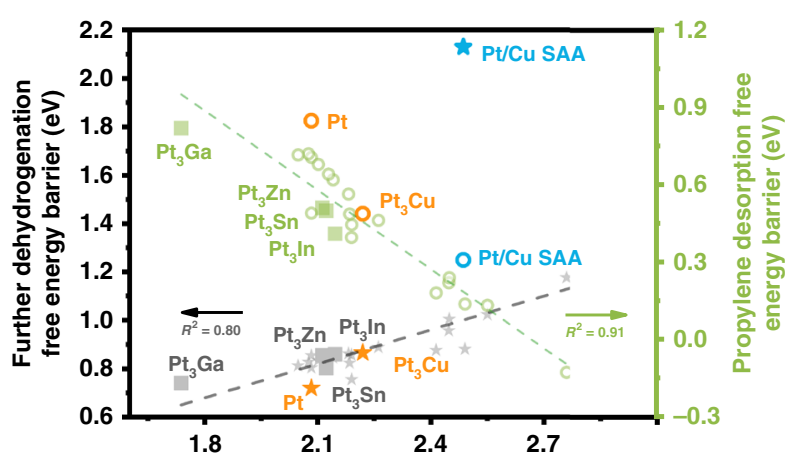

First dehydrogenation step free energy barrier $(\mathrm{eV})$

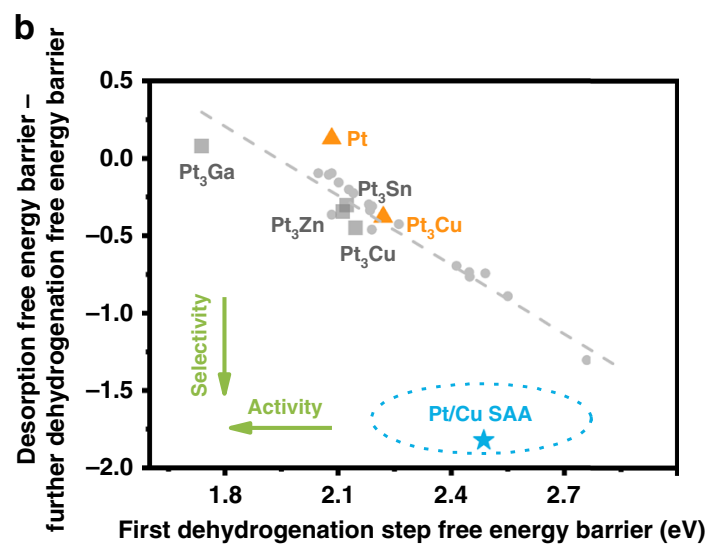

d

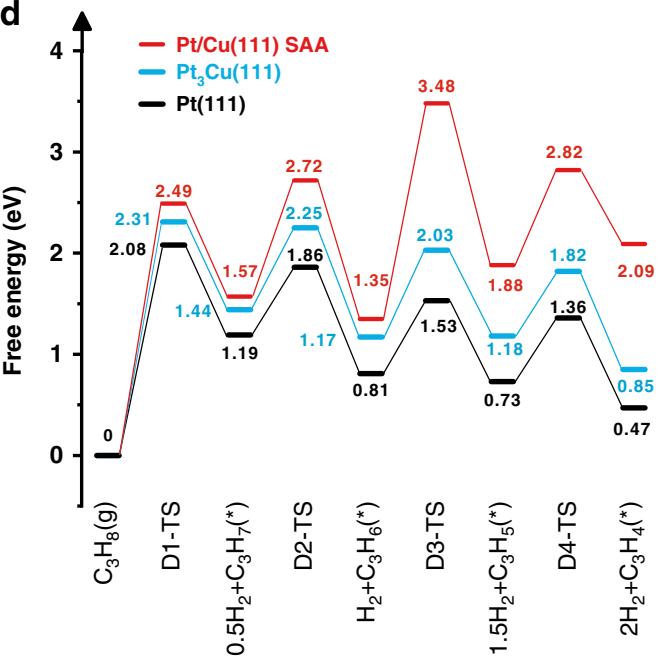

C

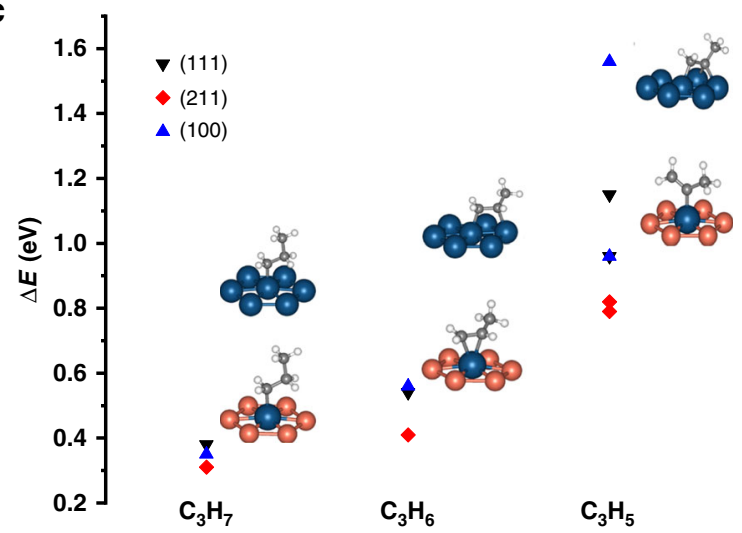

Fig. $1 \mathrm{Pt} / \mathrm{Cu}$ SAA breaking the PtM alloy scaling relationship for PDH. a Scaling relationship between first dehydrogenation barrier and propylene desorption barrier/deep dehydrogenation barrier (highest barrier from di- $\sigma$ propylene to $\mathrm{C}_{3} \mathrm{H}_{4}$ ), data for the $\mathrm{Pt}_{3} \mathrm{M}$ alloy systems are obtained from ref. ${ }^{11}$. b Screening of Pt-based bimetallic catalyst for $\mathrm{PDH}$, data for the $\mathrm{Pt}_{3} \mathrm{M}$ alloy systems are obtained from ref. ${ }^{11}$. c Binding energy difference and structures (on (111) surface only) of dehydrogenated intermediates $\mathrm{C}_{3} \mathrm{H}_{x}(x=7,6,5)$ over pure Pt surfaces and Pt/Cu SAA surfaces. The $\Delta E$ is defined as $E_{a d s}$ (on Pt/Cu SAA surfaces) $-E_{\text {ads }}$ (on Pt surfaces). Color: $\mathrm{Pt}$-blue; $\mathrm{Cu}$-orange; $\mathrm{C}$-gray; $\mathrm{H}$-white. $\mathbf{d}$ Energy profiles of $\mathrm{PDH}$ over $\mathrm{Pt} / \mathrm{Cu} \mathrm{SAA}, \mathrm{Pt} \mathrm{C}_{3} \mathrm{Cu}(111)$ and $\mathrm{Pt}(111)$

slightly increases the corresponding dehydrogenation barriers by $\sim 0.4 \mathrm{eV}$, resulting in similar $\mathrm{PDH}$ activity over pure $\mathrm{Pt}$ and $\mathrm{Pt} / \mathrm{Cu}$ SAA (Fig. 1d). Note that our convergence test suggests $\mathrm{Pt} / \mathrm{Cu}$ (111) surface model can well describe $\mathrm{Pt} / \mathrm{Cu}$ SAA nanoparticles which are larger than $2.1 \mathrm{~nm}$ in diameter $\left(\mathrm{Pt} / \mathrm{Cu}_{404}\right.$, Supplementary Figure 2). Similar behavior has also been observed for single $\mathrm{Pt}$ atom over $\mathrm{Cu}(100)$ and $\mathrm{Cu}(211)$ surfaces (Supplementary Figure 3).

DFT results also identify that the exposed isolated surface $\mathrm{Pt}$ atoms within $\mathrm{Cu}(111)$ facets of $\mathrm{Pt} / \mathrm{Cu}$ SAA nanoparticles (larger than $2.1 \mathrm{~nm}$ in diameter) are thermodynamically more stable than other types of Pt species: (1) isolated subsurface Pt atoms, (2) single Pt atoms within $\mathrm{Cu}(100)$ facets, (3) single Pt atoms at low coordinated step edge and corner sites, and (4) surface dimers within $\mathrm{Cu}(111)$ (Supplementary Tables 2-4). Therefore, isolated Pt atoms within $\mathrm{Cu}(111)$ facets are thermodynamically preferred in the case with high $\mathrm{Cu}$ to $\mathrm{Pt}$ molar ratio, which maximizes the utilization of $\mathrm{Pt}$ atoms.

Therefore, it is reasonable to speculate that the catalysts based on $\mathrm{Pt} / \mathrm{Cu} \mathrm{SAA}$ have the potential to achieve a decent catalytic performance for $\mathrm{PDH}$. Note that we also calculated the relative stability of $\mathrm{Pt} / \mathrm{Ag}$ SAA surfaces, and the single $\mathrm{Pt}$ atom is always slightly more stable at subsurface instead of surface. Although the dehydrogenation barrier is similar for $\mathrm{Pt} / \mathrm{Cu}(111)$ and $\mathrm{Pt} / \mathrm{Ag}(111)$ SAA surfaces (Supplementary Figure 4), the catalytic activity for
$\mathrm{Pt} / \mathrm{Ag}(111)$ might be low due to the less exposed surface Pt atoms over Ag.

Preparation of Pt/Cu SAA via atomic dilution. We simply synthesized the catalysts with $\mathrm{Pt} / \mathrm{Cu}$ SAA supported on $\gamma$-alumina by means of atomic dilution. Only diffraction lines due to $\gamma$ alumina were detected in the XRD patterns of the catalysts after calcination (Supplementary Figure 5a), suggesting $\mathrm{Cu}$ oxide species are highly dispersed on the surface of alumina. When treated under $\mathrm{H}_{2}$-rich condition at $600^{\circ} \mathrm{C}$ for $1 \mathrm{~h}$, the oxide species of $\mathrm{Pt}$ and $\mathrm{Cu}$ on $\gamma$-alumina can be fully reduced since the highest reduction peak temperature for $\mathrm{PtCu}$ bimetallic catalysts is below $200^{\circ} \mathrm{C}$ (Supplementary Figure 6). For the catalysts after reduction, the diffraction line of $\mathrm{Cu}(111)$ becomes apparent as the content of $\mathrm{Cu}$ increases to $6.7 \mathrm{wt} \%$, demonstrating the formation of $\mathrm{Cu}$ nanoparticles on alumina (Supplementary Figure 5b). Given the appearance of the co-reduction peaks (Supplementary Figure 6), the close contact between $\mathrm{Cu}$ oxide species and $\mathrm{Pt}$ oxide species leads to preferential formation of $\mathrm{PtCu}$ bimetallic nanoparticles rather than two metal phases apart from each other during reduction. The $\mathrm{PtCu}$ bimetallic nanoparticles formed on $\gamma-\mathrm{Al}_{2} \mathrm{O}_{3}$ during reduction in the $\mathrm{H}_{2}$-rich atmosphere at high temperatures can be considered as a $\mathrm{Pt} / \mathrm{Cu}$ surface alloy, as $\mathrm{Pt}$ is preferentially dispersed on the surface layer of $\mathrm{PtCu}$ alloys ${ }^{29,44}$. 

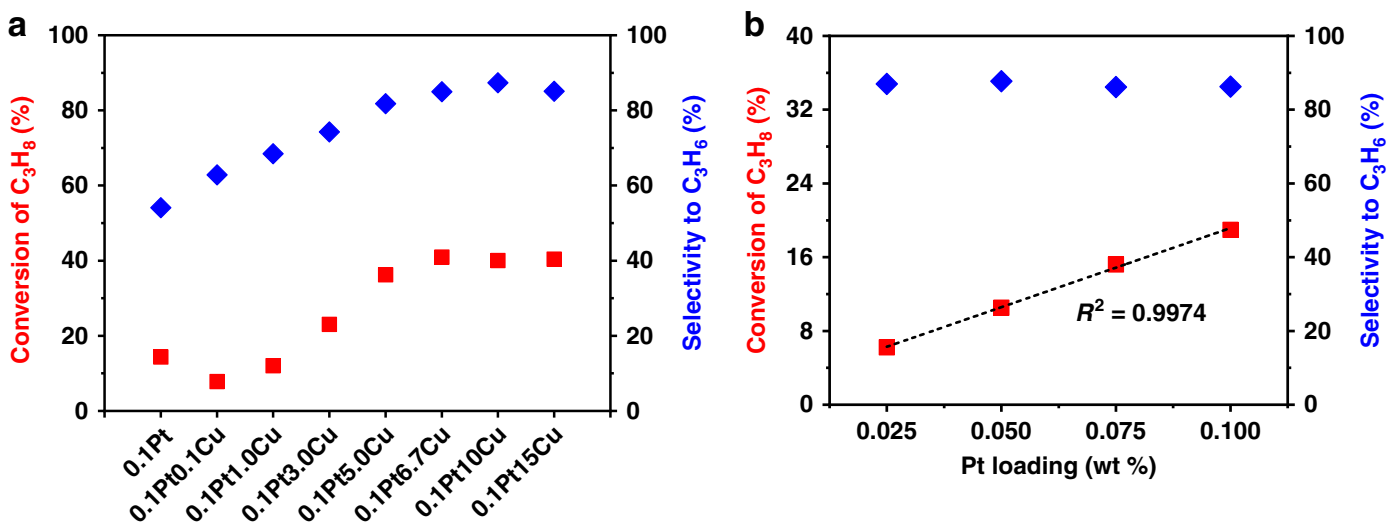

Fig. 2 Initial activity as a function of Pt/Cu atom ratio. a The initial activities of the catalysts with fixed amount of Pt (0.1 wt\%) and increasing content of $\mathrm{Cu}$ $(0,0.1,0.3,3,5,6.7,10$, and $15 \mathrm{wt} \%)$. With the $\mathrm{Cu} / \mathrm{Pt}$ atom ratio increasing, the initial conversion of propane first rises and then remains unchanged, implying a critical $\mathrm{Cu} / \mathrm{Pt}$ molar ratio for the formation of Pt/Cu SAA. b The initial activities of the catalysts with fixed amount of $\mathrm{Cu}(10 \mathrm{wt} \%)$ and progressively decreasing content of $\mathrm{Pt}(0.1,0.075,0.05$, and $0.025 \mathrm{wt} \%)$. The excellent linear correlation between the initial activity and $\mathrm{Pt}$ concentration supports the formation of Pt/Cu SAA. Catalytic conditions: atmospheric pressure, $600{ }^{\circ} \mathrm{C}, \mathrm{C}_{3} \mathrm{H}_{8} / \mathrm{H}_{2}=1 / 1$, with balance $\mathrm{N}_{2}$ for total flow rate of $50 \mathrm{~mL}$ min -1 , WHSV of propane $=4 \mathrm{~h}^{-1}$ and $250 \mathrm{mg}$ of sample (a) or WHSV of propane $=40 \mathrm{~h}^{-1}$ and $25 \mathrm{mg}$ of sample (b)

Then with the amount of Pt fixed, further addition of $\mathrm{Cu}$ lowers the concentration of $\mathrm{Pt}$ in the $\mathrm{Pt} / \mathrm{Cu}$ surface alloy leading to easier formation of Pt/Cu SAA. It can be expected that $\mathrm{Pt}$ atoms would be individually dispersed in $\mathrm{Cu}$ nanoparticles if diluted to a certain degree and the structure would stay the same with further dilution.

To verify the above conjecture, we compared the initial activities of the catalysts with fixed amount of Pt ( $0.1 \mathrm{wt} \%)$ but various contents of $\mathrm{Cu}$ (Fig. 2a). As expected, the initial conversion of propane increases until the content of $\mathrm{Cu}$ reaches $6.7 \mathrm{wt} \%$ and then remains unchanged with the amount of $\mathrm{Cu}$ further increasing to $15 \mathrm{wt} \%$. Hence, we presume that the formation of $\mathrm{Pt} / \mathrm{Cu} \mathrm{SAA}$ on $\gamma$-alumina can be achieved for the catalysts with the addition of $\mathrm{Cu}$ no less than $6.7 \mathrm{wt} \%$. Furthermore, given the assumption that $\mathrm{Pt}$ atoms are individually dispersed in $\mathrm{Cu}$ nanoparticles for $0.1 \mathrm{Pt} 10 \mathrm{Cu} / \mathrm{Al}_{2} \mathrm{O}_{3}$, keeping the content of $\mathrm{Cu}(10 \mathrm{wt} \%)$ unchanged, we decreased progressively the amount of Pt from $0.1 \mathrm{wt} \%$ to $0.025 \mathrm{wt} \%$, which guarantees the structure unchanged. The initial activity correlates linearly with the Pt content, which again suggests the formation of $\mathrm{Pt} / \mathrm{Cu}$ SAA (Fig. 2b). Note that the intersection of the fitting line with $Y$ axis is not zero, which is attributed to the weak catalytic ability of $\gamma$-alumina-supported $\mathrm{Cu}$.

Formation of Pt/Cu SAA. The structure of Pt/Cu SAA supported on $\gamma$-alumina was confirmed by CO-DRIFTS, AC-HAADF-STEM images and EXAFS spectra. As shown in the in situ DRIFTS, the weak bands caused by bridge-adsorbed $\mathrm{CO}$ on two adjacent $\mathrm{Pt}$ atoms appear at around $1835 \mathrm{~cm}^{-1}$ for $0.1 \mathrm{Pt} / \mathrm{Al}_{2} \mathrm{O}_{3}$ and $0.1 \mathrm{Pt} 0.1 \mathrm{Cu} / \mathrm{Al}_{2} \mathrm{O}_{3}$ (Supplementary Figure $7 \mathrm{a}, \mathrm{b}$ ), indicating the existence of dimers or clusters of $\mathrm{Pt}^{45}$. Meanwhile, the lack of the band of bridge-bonded $\mathrm{CO}$ on other catalysts suggests the exclusively isolated $\mathrm{Pt}$ atoms or low concentrations of bridging $\mathrm{CO}^{46,47}$. For $0.1 \mathrm{Pt} / \mathrm{Al}_{2} \mathrm{O}_{3}$, Fig. 3a shows a main band at $2068 \mathrm{~cm}^{-1}$, which can be assigned as linearly adsorbed $\mathrm{CO}$ on $\mathrm{Pt}$ nanoparticles. For $\mathrm{CO}$ adsorption on $0.1 \mathrm{Pt} 0.1 \mathrm{Cu} / \mathrm{Al}_{2} \mathrm{O}_{3}, 0.1 \mathrm{Pt} 0.3 \mathrm{Cu} / \mathrm{Al}_{2} \mathrm{O}_{3}$, and $0.1 \mathrm{Pt} 3 \mathrm{Cu} / \mathrm{Al}_{2} \mathrm{O}_{3}$, the bands due to linearly bonded $\mathrm{CO}$ on $\mathrm{Pt}$ ensembles on PtCu bimetallic nanoparticles appear at 2063-2044 $\mathrm{cm}^{-1}$ (Fig. 3b-d). The unique band centered at $2018 \mathrm{~cm}^{-1}$ emerges in the spectra of $0.1 \mathrm{Pt} 3 \mathrm{Cu} / \mathrm{Al}_{2} \mathrm{O}_{3}, 0.1 \mathrm{Pt} 6.7 \mathrm{Cu} / \mathrm{Al}_{2} \mathrm{O}_{3}$, and $0.1 \mathrm{Pt1} 10 \mathrm{Cu} / \mathrm{Al}_{2} \mathrm{O}_{3}$ (Fig. 3d-f), which can be attributed to linearly bonded $\mathrm{CO}$ on single atoms of $\mathrm{Pt}$ in the metallic state ${ }^{48}$, differing from those at $2080-2115 \mathrm{~cm}^{-1}$ ascribed to CO linearly adsorbed on $\mathrm{Pt}^{\delta+}$ single-atom sites on metal oxides ${ }^{45,49-51}$. Note that our DFT calculations predict the top-adsorbed CO stretching frequencies are $2061 \mathrm{~cm}^{-1}$ over $\mathrm{Pt}(111)$ and $2021 \mathrm{~cm}^{-1}$ over $\mathrm{Pt} / \mathrm{Cu}$ SAA, which are very close to experimentally observed locations (Supplementary Table 5). Combining the fact that there are no bands due to $\mathrm{CO}$ on Pt ensembles detected for $0.1 \mathrm{Pt} 6.7 \mathrm{Cu} / \mathrm{Al}_{2} \mathrm{O}_{3}$ and $0.1 \mathrm{Pt} 10 \mathrm{Cu} / \mathrm{Al}_{2} \mathrm{O}_{3}$, it can be inferred that Pt atoms on the surface of $\mathrm{Cu}$ nanoparticles are individually dispersed. It is worth pointing out that the variation trend of $\mathrm{CO}$ adsorption behavior is highly consistent with that of the initial activities of the catalysts as the $\mathrm{Cu}$ content increases.

The structure of $\mathrm{Pt} / \mathrm{Cu} \mathrm{SAA}$ was further addressed by ACHAADF-STEM images. Single Pt atoms can be distinguished from $\mathrm{Cu}$ atoms due to differences in the $\mathrm{Z}$-contrast ${ }^{29,52}$. Figure $4 \mathrm{a}$ indicates the presence of individual brighter $\mathrm{Pt}$ atoms in $\mathrm{Cu}$ nanoparticles. As a contrast, we failed to find $\mathrm{Pt}$ atoms over the $10 \mathrm{Cu} / \mathrm{Al}_{2} \mathrm{O}_{3}$ catalyst (Fig. $4 \mathrm{e}$ and Supplementary Figure 11). The lattice spacing of $\mathrm{Pt} / \mathrm{Cu} \mathrm{SAA}$ is $0.21 \mathrm{~nm}$, which is in good consistence with the lattice spacing of $\mathrm{Cu}(111)$, indicating dilute dispersion of $\mathrm{Pt}$ atoms in $\mathrm{Cu}$ nanoparticles. Single $\mathrm{Pt}$ atoms in $\mathrm{Cu}$ nanoparticles are repeatedly observed in different regions of the reduced $0.1 \mathrm{Pt} 10 \mathrm{Cu} / \mathrm{Al}_{2} \mathrm{O}_{3}$ catalyst, and no clusters or nanoparticles of Pt on $\gamma$-alumina are found (Supplementary Figures 9, 10, and 23). In terms of $0.1 \mathrm{Pt} / \mathrm{Al}_{2} \mathrm{O}_{3}$, the $\mathrm{Pt}$ nanoparticles are dispersed on $\gamma$-alumina with an average particle size of about $2.3 \mathrm{~nm}$ (Supplementary Figure 8). In situ EXAFS performed at the $\mathrm{Pt}-\mathrm{L}_{\mathrm{III}}$ edge and $\mathrm{Cu}-\mathrm{K}$ edge reveals the coordination of $\mathrm{Pt}$ and $\mathrm{Cu}$ in monometallic $\mathrm{Pt}$ and bimetallic $\mathrm{PtCu}$ catalysts (Supplementary Figures $12-19$ and Table 7 ). At the Pt- $\mathrm{L}_{\text {III }}$ edge, there are $\sim 6.8$ $\mathrm{Pt}-\mathrm{Cu}$ bonds at $2.53 \AA$ and no Pt-Pt coordination is detected in the fully reduced $0.1 \mathrm{Pt} 6.7 \mathrm{Cu} / \mathrm{Al}_{2} \mathrm{O}_{3}$ catalyst, providing direct evidence for the isolated $\mathrm{Pt}$ atoms in the bimetallic $\mathrm{PtCu}$ catalysts at high $\mathrm{Cu}$ to $\mathrm{Pt}$ molar ratios. Due to the low Pt loading, at the $\mathrm{Cu}-\mathrm{K}$ edge, there are only $7.0 \mathrm{Cu}-\mathrm{Cu}$ bonds at $2.55 \AA$ consistent with $2 \mathrm{~nm}$ metallic $\mathrm{Cu}$ nanoparticles. For the $0.1 \mathrm{Pt} / \mathrm{Al}_{2} \mathrm{O}_{3}$ catalyst, the existence of $\mathrm{Pt}-\mathrm{Pt}$ coordination indicates the formation of $\mathrm{Pt}$ islands and/or clusters.

C-H activation studies. Temperature-programmed surface reaction (TPSR) analysis was used to evaluate the intrinsic activity of the catalysts for PDH. We examined the TPSR over $\gamma$-aluminasupported $\mathrm{Pt}$ nanoparticles, $\mathrm{Pt} / \mathrm{Cu} \mathrm{SAA}$, and $\mathrm{Cu}$ nanoparticles for propane-deuterium isotope scrambling (P-D scrambling) to 

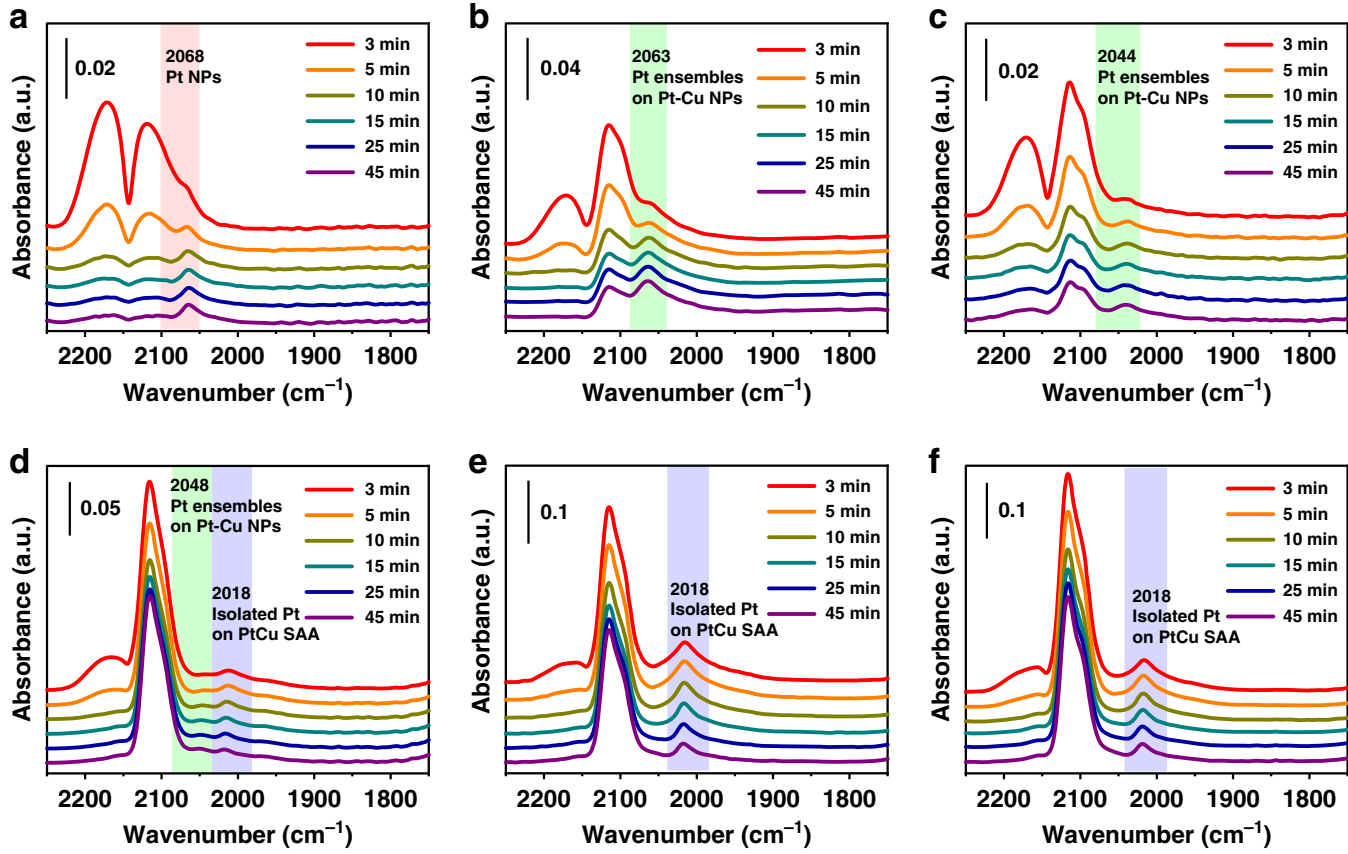

Fig. 3 In situ CO-DRIFTS for the catalysts with fixed Pt but increasing Cu contents. a 0.1Pt/ $/ \mathrm{Al}_{2} \mathrm{O}_{3}, \mathbf{b} 0.1 \mathrm{Pt} 0.1 \mathrm{Cu} / \mathrm{Al}_{2} \mathrm{O}_{3}, \mathbf{c} 0.1 \mathrm{PtO} .3 \mathrm{Cu} / \mathrm{Al} \mathrm{O}_{3}$, d $0.1 \mathrm{Pt} 3 \mathrm{Cu} /$ $\mathrm{Al}_{2} \mathrm{O}_{3}$, e $0.1 \mathrm{Pt} 6.7 \mathrm{Cu} / \mathrm{Al}_{2} \mathrm{O}_{3}$ and $\mathbf{f} 0.1 \mathrm{Pt} 10 \mathrm{Cu} / \mathrm{Al}_{2} \mathrm{O}_{3}$. As $\mathrm{Pt}$ is continuously diluted with $\mathrm{Cu}$, the band of $\mathrm{CO}$ linearly adsorbed on $\mathrm{Pt}$ firstly redshifts from $2068 \mathrm{~cm}^{-1}$ to $2044 \mathrm{~cm}^{-1}$ and then an exclusively band at $2018 \mathrm{~cm}^{-1}$ appears and remains unchanged with further increasing the Cu content. The band at $2018 \mathrm{~cm}^{-1}$ is ascribed to CO linearly adsorbed on single atoms of Pt in the metallic state
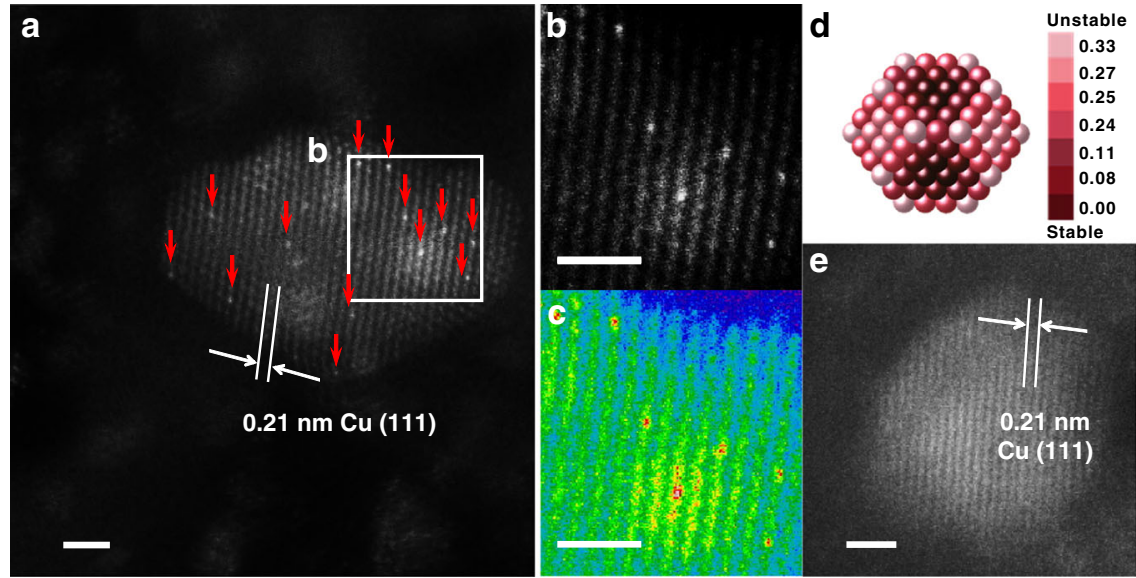

Fig. 4 Morphology of $\gamma-\mathrm{Al}_{2} \mathrm{O}_{3}$-supported Pt/Cu SAA. a HAADF-STEM images with typical region of the reduced $0.1 \mathrm{Pt} 10 \mathrm{Cu} / \mathrm{Al} \mathrm{O}_{2} \mathrm{O}$ catalyst, showing Pt atoms individually dispersed on $\mathrm{Cu}(111)$. Pt atoms are highlighted by red arrows. b, $\mathbf{c}$ The enlarged image and the colored intensity map from the selected region in $\mathbf{a}$. The lattice spacing of Pt/Cu SAA is $0.21 \mathrm{~nm}$, which is consistent with that of $\mathrm{Cu}(111)$. d Relative stability of Pt single atoms over $\mathrm{Cu}(\sim 2.1 \mathrm{~nm})$ nanoparticle: dark red indicates stable location of Pt atom. Color bar unit is eV/Pt atom. e HAADF-STEM images with typical region of the reduced 10Cu/ $\mathrm{Al}_{2} \mathrm{O}_{3}$ catalyst, showing no Pt atoms existing on the surface of $\mathrm{Cu}$ nanoparticles. Scale bars, $1 \mathrm{~nm}(\mathbf{a}),(\mathbf{b}),(\mathbf{c})$ and (e)

compare their intrinsic ability to activate the $\mathrm{C}-\mathrm{H}$ bonds of propane ${ }^{53,54}$. The $\mathrm{C}-\mathrm{H}$ activation starts at about $188^{\circ} \mathrm{C}$ on $\mathrm{Pt}$ nanoparticles, $204^{\circ} \mathrm{C}$ on $\mathrm{Pt} / \mathrm{Cu} \mathrm{SAA}$, and $298^{\circ} \mathrm{C}$ on $\mathrm{Cu}$ nanoparticles, respectively (Fig. 5a). Moreover, according to the $\mathrm{Pt}$ dispersion (Supplementary Table 8 ) and the specific activity at $520^{\circ} \mathrm{C}$ (Supplementary Table 9), the calculated TOF is $0.72 \mathrm{~s}^{-1}$ for $0.1 \mathrm{Pt} / \mathrm{Al}_{2} \mathrm{O}_{3}$ and $0.56 \mathrm{~s}^{-1}$ for $0.1 \mathrm{Pt} 10 \mathrm{Cu} / \mathrm{Al}_{2} \mathrm{O}_{3}$. Note that the TOF value is quite close to that reported for $\mathrm{Pt}$ nanoparticles supported on calcined hydrotalcite ${ }^{53}$. Combining the results of TPSR of P-D scrambling and TOFs, we conclude that the intrinsic activity of $\mathrm{Pt} / \mathrm{Cu}$ SAA for $\mathrm{PDH}$ is only slightly lower than that of $\mathrm{Pt}$ nanoparticle while $\mathrm{Cu}$ nanoparticles presents an extremely low capacity for $\mathrm{C}-\mathrm{H}$ activation. This supports the slightly increased dehydrogenation barrier for Pt/Cu SAA compared with $\mathrm{Pt}(111)$ identified in the DFT studies.

Catalytic performance. We examined the catalytic performances of $0.1 \mathrm{Pt} / \mathrm{Al}_{2} \mathrm{O}_{3}$ and $0.1 \mathrm{Pt} 10 \mathrm{Cu} / \mathrm{Al}_{2} \mathrm{O}_{3}$ for $\mathrm{PDH}$ to demonstrate the transferability from DFT calculations to practical catalytic reaction. During the $\mathrm{PDH}$ at $520^{\circ} \mathrm{C}$, the propylene formation rate dramatically dropped from 3.7 to $1.6 \mathrm{~mol} \mathrm{~g}^{-1} \mathrm{Pt}^{-1}$ for $0.1 \mathrm{Pt} /$ $\mathrm{Al}_{2} \mathrm{O}_{3}$ after $12 \mathrm{~h}$ on stream (Fig. 5b). As a contrast, we did not observe deactivation for $0.1 \mathrm{Pt} 10 \mathrm{Cu} / \mathrm{Al}_{2} \mathrm{O}_{3}$ upon $12 \mathrm{~h}$ on stream (Fig. 5b) and the propylene formation rate only slightly decreased from 10.6 to $10.3 \mathrm{~mol} \mathrm{~g}^{-1} \mathrm{Pt}^{-1}$ even after $120 \mathrm{~h}$ on stream 
a

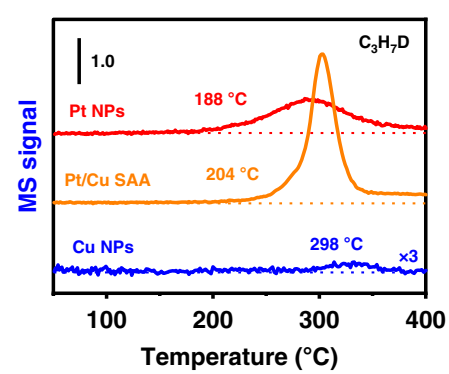

d

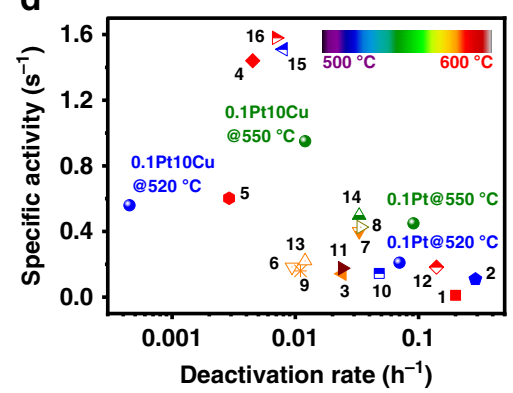

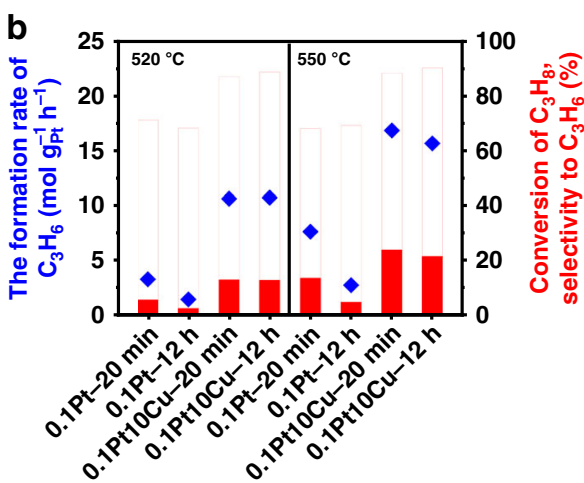
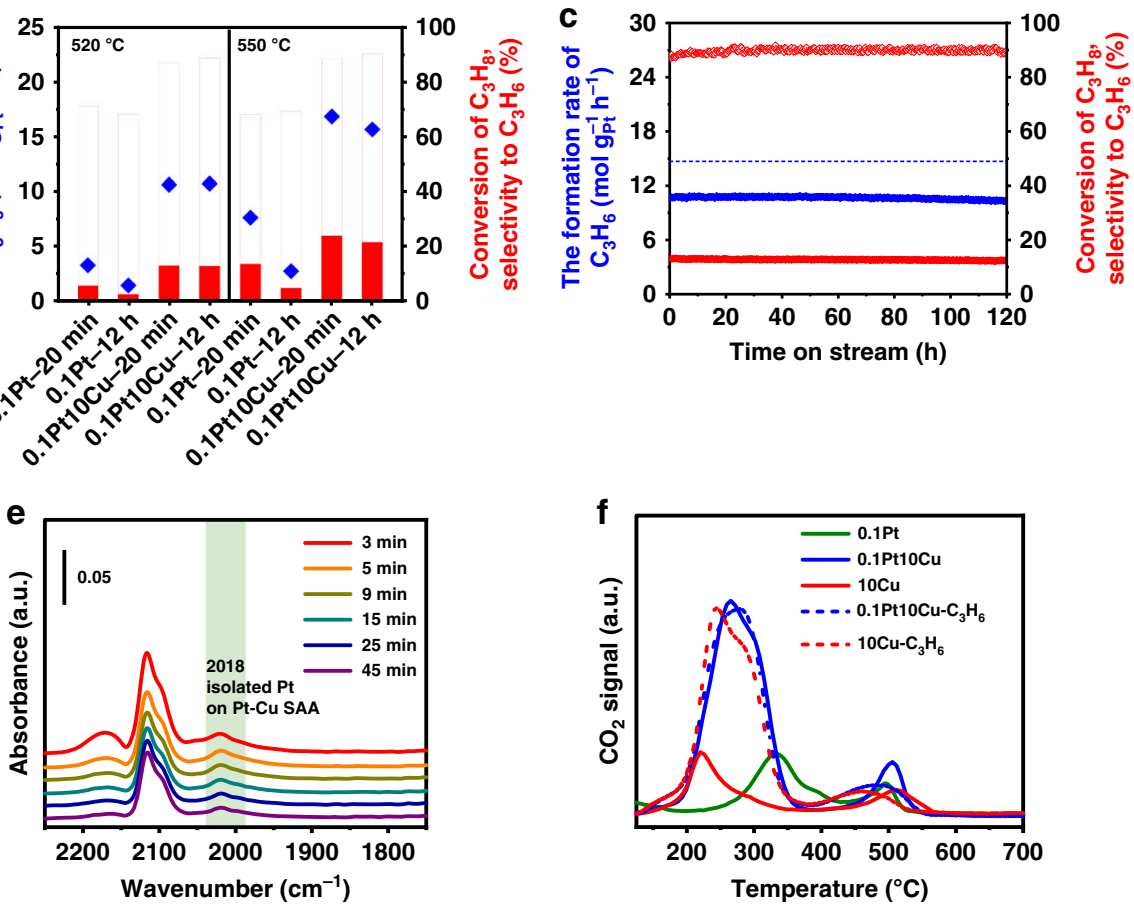

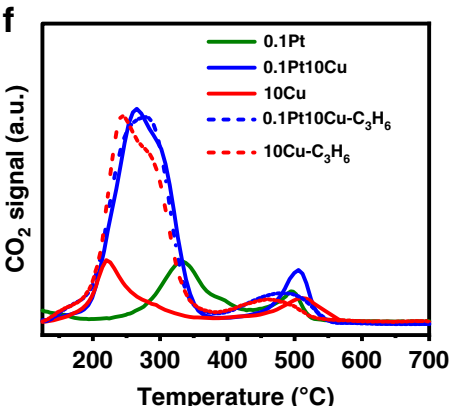

Fig. 5 Catalytic performances and characterizations of spent catalysts. a Signals of $\mathrm{C}_{3} \mathrm{H}_{7} \mathrm{D}$ during TPSR over $0.3 \mathrm{Pt} / \mathrm{Al}_{2} \mathrm{O}_{3}, 0.1 \mathrm{Pt10Cu} / \mathrm{Al} \mathrm{O}_{3}$ and $10 \mathrm{Cu} /$ $\mathrm{Al}_{2} \mathrm{O}_{3}$ for $\mathrm{P}-\mathrm{D}$ scrambling. The mass ratio of $45 / 44$ represents the level of $\mathrm{C}_{3} \mathrm{H}_{7} \mathrm{D}$. Compared with Pt nanoparticles, a little higher temperature of $\mathrm{C}-\mathrm{H}$ activation for Pt/Cu SAA suggests a slightly weaker intrinsic activity of dehydrogenation. $\mathbf{b}$ Catalytic performances at the initial and final period at $520{ }^{\circ} \mathrm{C}$ and $550^{\circ} \mathrm{C}$ during $12 \mathrm{~h} \mathrm{PDH}$, showing significantly improved performances of Pt/Cu SAA compared with Pt nanoparticles. c Long-term stability test for $0.1 \mathrm{Pt} 10 \mathrm{Cu} / \mathrm{Al}_{2} \mathrm{O}_{3}$ at $520^{\circ} \mathrm{C}$ for $120 \mathrm{~h}$, demonstrating its excellent stability. The thermodynamic conversion calculated as mole $\mathrm{g}^{-1} \mathrm{Pt} \mathrm{h}^{-1}$ is presented (dash line). d Normalized activities of the formation rate of $\mathrm{C}_{3} \mathrm{H}_{6}$ by specific content of $\mathrm{Pt}$ for the catalysts described in this work and in the literature (1-16, see Supplementary Table 10). e CO-DRIFTS of $0.1 \mathrm{Pt} 10 \mathrm{Cu} / \mathrm{Al}_{2} \mathrm{O}_{3}$ after long-term stability test, showing the maintainance of the sturcture of Pt/Cu SAA. f Mass-spectra signals of $\mathrm{CO}_{2}$ during TPO experiments for the spent catalysts of $0.1 \mathrm{Pt} / \mathrm{Al}_{2} \mathrm{O}_{3}, 0.1 \mathrm{Pt} 10 \mathrm{Cu} / \mathrm{Al}_{2} \mathrm{O}_{3}$, and $10 \mathrm{Cu} / \mathrm{Al}_{2} \mathrm{O}_{3}$ after $12 \mathrm{~h} \mathrm{PDH}$ at $520{ }^{\circ} \mathrm{C}$ and for the catalysts of $0.1 \mathrm{Pt} 10 \mathrm{Cu} / \mathrm{Al}_{2} \mathrm{O}_{3}$ and $10 \mathrm{Cu} / \mathrm{Al}_{2} \mathrm{O}_{3}$ with treatment in the flow of $\mathrm{C}_{3} \mathrm{H}_{6} / \mathrm{N}_{2} / \mathrm{H}_{2}=1 / 41 / 8 \mathrm{~mL} \mathrm{~min}^{-1}$ at $52 \mathrm{O}^{\circ} \mathrm{C}$. The TPO profile of $\mathrm{Pt} / \mathrm{Cu} \mathrm{SAA}$ is very close to that of $\mathrm{Cu}$ nanoparticles, verifying its excellent anti-coke capability. Catalytic test conditions: atmospheric pressure, WHSV propane $=4 \mathrm{~h}^{-1}, 250 \mathrm{mg}$ of sample, $\mathrm{C}_{3} \mathrm{H}_{8} / \mathrm{H}_{2}=1 / 1$, with balance $\mathrm{N}_{2}$ for total flow rate of $50 \mathrm{~mL} \mathrm{~min}^{-1}$

(Fig. 5c). The initial propylene formation rate for $0.1 \mathrm{Pt} 10 \mathrm{Cu} /$ $\mathrm{Al}_{2} \mathrm{O}_{3}$ is 3.2 times of that for $0.1 \mathrm{Pt} / \mathrm{Al}_{2} \mathrm{O}_{3}$, at the same time the selectivity to propylene improves to $90 \%$ for $0.1 \mathrm{Pt} 10 \mathrm{Cu} / \mathrm{Al}_{2} \mathrm{O}_{3}$ at $13.1 \%$ conversion compared with $70 \%$ for $0.1 \mathrm{Pt} / \mathrm{Al}_{2} \mathrm{O}_{3}$ at $5.8 \%$ conversion. Although DFT calculations predict slightly increased dehydrogenation barrier for $\mathrm{Pt} / \mathrm{Cu} \mathrm{SAA}$, its higher propylene formation rate can be attributed to its better Pt dispersion compared with $0.1 \mathrm{Pt} / \mathrm{Al}_{2} \mathrm{O}_{3} \quad(\mathrm{Pt}$ dispersion $=29 \%)$. In terms of deactivation, a first-order deactivation model is used to estimate the catalyst stability ${ }^{55}$. The low deactivation rate of $0.0005 \mathrm{~h}^{-1}$ for $0.1 \mathrm{Pt} 10 \mathrm{Cu} / \mathrm{Al}_{2} \mathrm{O}_{3}$ quantitatively demonstrates its high stability when compared to $0.07 \mathrm{~h}^{-1}$ for $0.1 \mathrm{Pt} / \mathrm{Al}_{2} \mathrm{O}_{3}$ (Supplementary Table 9). To further test the stability of the catalysts, the reaction temperature was increased to $550^{\circ} \mathrm{C}$ (Fig. $5 \mathrm{~b}$ and Supplementary Figure 24). During $12 \mathrm{~h} \mathrm{PDH}$, the formation rate of propylene dropped from 7.7 to $2.8 \mathrm{~mol} \mathrm{~g}-1 \mathrm{Pt}^{-1}$ for $0.1 \mathrm{Pt} / \mathrm{Al}_{2} \mathrm{O}_{3}$, corresponding to the deactivation rate of $0.091 \mathrm{~h}^{-1}$. While for $0.1 \mathrm{Pt} 10 \mathrm{Cu} / \mathrm{Al}_{2} \mathrm{O}_{3}$, the formation rate of propylene only decreased from 16.8 to $15.8 \mathrm{~mol} \mathrm{~g}^{-1} \mathrm{Pt}^{-1}$ and the deactivation rate became $0.012 \mathrm{~h}^{-1}$, verifying its higher activity and better coke resistance. In addition, we examined the performance of $0.1 \mathrm{Pt} 10 \mathrm{Cu} / \mathrm{Al}_{2} \mathrm{O}_{3}$ for successive oxidation-reduction cycles. The conversion and selectivity of the catalyst had no change during five cycles at $520{ }^{\circ} \mathrm{C}$ (Supplementary Figure 25), demonstrating its good stability of dehydrogenation and regeneration. The initial activity of the catalyst can be largely restored after regeneration at $600^{\circ} \mathrm{C}$ (Supplementary Figure 28), further confirming its cycle stability.
The activity of the $10 \mathrm{Cu} / \mathrm{Al}_{2} \mathrm{O}_{3}$ catalyst for $\mathrm{PDH}$ was very low, which can be neglected compared to that of the $0.1 \mathrm{Pt} 10 \mathrm{Cu} / \mathrm{Al}_{2} \mathrm{O}_{3}$ catalyst (Supplementary Figure 31).

We prepared the Pt/Ag SAA catalyst according to similar atomic dilution method mentioned above. The TPSR of P-D scrambling experiment indicates similar $\mathrm{C}-\mathrm{H}$ activation ability between Pt/Ag SAA and Pt/Cu SAA (Supplementary Figure 20a). However, under reaction conditions, the propane conversion for $\mathrm{Pt} / \mathrm{Ag}$ SAA is only $32 \%$ at $600^{\circ} \mathrm{C}$, which is lower than $41 \%$ for Pt/ $\mathrm{Cu}$ SAA, consistent with the DFT predicted trends (Supplementary Figure 20b and Supplementary Table 6).

Spent catalysts. The spent catalysts were characterized to further shed light on the relationship between the improved reaction rate and stability and the structure of Pt/Cu SAA. DRIFTS of CO on the spent $0.1 \mathrm{Pt} 10 \mathrm{Cu} / \mathrm{Al}_{2} \mathrm{O}_{3}$ (Fig. 5e) show that surface $\mathrm{Pt}$ atoms are still individually dispersed even after a long-term stability test for $120 \mathrm{~h}$ on stream at $520^{\circ} \mathrm{C}$, which suggests the atomic dispersion of $\mathrm{Pt}$ in $\mathrm{Cu}$ is maintained during the $\mathrm{PDH}$ reaction. The slightly increased particle size of the bimetallic nanoparticles on $\mathrm{Al}_{2} \mathrm{O}_{3}$ after reaction indicates the thermal stability of the catalyst at $520{ }^{\circ} \mathrm{C}$ (Supplementary Figure 32 ). When the reaction temperature was raised to $600{ }^{\circ} \mathrm{C}$, the sintering of copper nanoparticles was obvious (Supplementary Figure 33), which may contribute to the quick deactivation of $0.1 \mathrm{Pt} 10 \mathrm{Cu} / \mathrm{Al}_{2} \mathrm{O}_{3}$ during the dehydrogenation reaction at $600{ }^{\circ} \mathrm{C}$. In addition, 
HAADF-STEM images of $0.1 \mathrm{Pt} 10 \mathrm{Cu} / \mathrm{Al}_{2} \mathrm{O}_{3}$ after successive oxidation-reduction cycles show that $\mathrm{Pt}$ atoms identified from their higher brightness comparing to their surrounding area are still individually dispersed in $\mathrm{Cu}$ nanoparticles, confirming its good cycle stability (Supplementary Figures 26, 27, 29, and 30). Regrettably, due to the lack of the EXAFS information for the regenerated $0.1 \mathrm{Pt} 10 \mathrm{Cu} / \mathrm{Al}_{2} \mathrm{O}_{3}$, the sintering of partial platinum cannot be fully ruled out. Considering that coke deposition is another reason for catalyst deactivation during propane dehydrogenation ${ }^{41}$, the information on the coke formed on the surface of $0.1 \mathrm{Pt} / \mathrm{Al}_{2} \mathrm{O}_{3}, 0.1 \mathrm{Pt} 10 \mathrm{Cu} / \mathrm{Al}_{2} \mathrm{O}_{3}$, and $10 \mathrm{Cu} / \mathrm{Al}_{2} \mathrm{O}_{3}$ were collected. The Raman spectra (Supplementary Figure 21) show that the $I_{\mathrm{D}} /$ $I_{\mathrm{G}}$ ratio increases in the order of $0.1 \mathrm{Pt} / \mathrm{Al}_{2} \mathrm{O}_{3}(0.76)<0.1 \mathrm{Pt} 10 \mathrm{Cu} /$ $\mathrm{Al}_{2} \mathrm{O}_{3}(0.82)<10 \mathrm{Cu} / \mathrm{Al}_{2} \mathrm{O}_{3}(0.86)$, suggesting a reverse order of dehydrogenation degree of the coke ${ }^{56}$. The temperatureprogrammed oxidation (TPO) profiles (Fig. 5f) indicate that there are two types of coke on each spent catalyst because of two peaks in each profile. We attribute the small high-temperature peaks centered at around $500^{\circ} \mathrm{C}$ to the combustion of the hard coke deposited on the support. While the main low-temperature peaks are described as the combustion of the soft coke formed on the metal, of which the temperatures decreased in the order of $0.1 \mathrm{Pt}\left(335^{\circ} \mathrm{C}\right)>0.1 \mathrm{Pt} 10 \mathrm{Cu}\left(265^{\circ} \mathrm{C}\right)>10 \mathrm{Cu}\left(225^{\circ} \mathrm{C}\right)^{56,57}$. The good consistence between the dehydrogenation degree of the coke and the burning temperature of the soft coke on the metal implies that the deep dehydrogenation reactivity decreases in the order of $\mathrm{Pt}$ nanoparticles, $\mathrm{Pt} / \mathrm{Cu} \mathrm{SAA}$, and $\mathrm{Cu}$ nanoparticles, which corroborates the trend of deep dehydrogenation barrier identified by the DFT calculations. Moreover, it is worth noting that the target propylene as coke precursor can partly transform into carbon deposits with the help of $\mathrm{Cu}$, which accounts for the formation of coke on $\mathrm{Pt} / \mathrm{Cu}$ SAA. As shown in Fig. 5f, after treating in the flow of propylene for the same time, the TPO profile of $0.1 \mathrm{Pt} 10 \mathrm{Cu} /$ $\mathrm{Al}_{2} \mathrm{O}_{3}$ is similar to that of $10 \mathrm{Cu} / \mathrm{Al}_{2} \mathrm{O}_{3}$, confirming the coke resistance of $0.1 \mathrm{Pt} 10 \mathrm{Cu} / \mathrm{Al}_{2} \mathrm{O}_{3}$ comparable with that of $10 \mathrm{Cu} /$ $\mathrm{Al}_{2} \mathrm{O}_{3}$. The temperature-programmed desorption (TPD) of propylene (Supplementary Figure 22) indicates that the interaction between the propylene and metal sites is weaker for $\mathrm{Cu}$ nanoparticles and Pt/Cu SAA than that for Pt nanoparticles. This weak interaction minimizes carbon deposits on the active Pt sites to help remain the activity during reaction.

\section{Discussion}

Our DFT calculation shows that different from the conventional $\mathrm{Pt}$ alloys, the Pt/Cu SAA breaks the PtM alloy scaling relationship during $\mathrm{PDH}$, displaying a quite negative difference between the desorption energy and further dehydrogenation barrier of propylene, and at the same time maintaining a reasonable dehydrogenation energy barrier for propane. We further synthesized a kind of SAA catalysts with single $\mathrm{Pt}$ atoms dispersed on $\mathrm{Cu}$ and $\mathrm{Ag}$ nanoparticles through an atom dilution method. In the catalytic dehydrogenation of propane, the $\mathrm{Pt} / \mathrm{Cu} \mathrm{SAA}$ catalyst with the low loading of Pt $(0.1 \mathrm{wt} \%)$ displays propylene selectivity of $\sim 90 \%$ with the high formation rate of $10.6 \mathrm{~mol} \mathrm{~g}^{-1} \mathrm{pt}^{-1}$ under the conditions of atmospheric pressure, $520^{\circ} \mathrm{C}$, WHSV $=4 \mathrm{~h}^{-1}$, $\mathrm{C}_{3} \mathrm{H}_{8} / \mathrm{N}_{2}=1 / 1$ and shows excellent stability for at least $120 \mathrm{~h}$ on stream. Our study highlights the transferability from the DFT calculations to the realistic catalytic system and implies isolated $\mathrm{Pt}$ atoms in the metallic state as promising active sites for alkane dehydrogenation at high temperatures.

\section{Methods}

Computational details. All the total energy self-consistent calculations were carried out in Vienna ab initio simulation package (VASP) ${ }^{58}$ using the generalized gradient approximation with the Bayesian error estimation functional with van der Waals corrections (BEEF-vdW $)^{59,60}$. We used the projector augmented-wave
(PAW) method to handle the ionic-core interaction ${ }^{61}$. The valence wave functions were expanded by plane-wave with a cutoff energy of $400 \mathrm{eV}$ and the electronic tolerance value is $1 \times 10^{-4} \mathrm{eV}$. A Methfessel-Paxton smearing with $0.15 \mathrm{eV}$ width was employed to speed up the convergence and the total energies were evaluated by extrapolating to zero broadening ${ }^{62}$. The thickness of the employed (111) slabs, separated by $>15 \AA$ vacuum layer, are five layers, with top two layers relaxed on each surface. Optimized geometries were found when the force on each relaxed atom was $<0.02 \mathrm{eV} / \AA$. The Monkhorst-Pack ${ }^{63} \mathrm{k}$-points mesh of $3 \times 3 \times 1$ was used in a $4 \times 4$ unit cell of each model slab. Test calculations indicate the numerical accuracy for the binding energies with finer k-points meshes is within $0.03 \mathrm{eV}$. We applied same parameters for the nanoparticle calculations, except the k-points grid was reduced to $\Gamma$ point.

Catalyst preparation. All the catalysts were prepared by incipient wetness coimpregnation method. $\mathrm{H}_{2} \mathrm{PtCl}_{6} \cdot 6 \mathrm{H}_{2} \mathrm{O}$ (Chemart (Tianjin) Chemical Technology Co., Ltd, 99.9\%) and $\mathrm{Cu}\left(\mathrm{NO}_{3}\right)_{2} \cdot 3 \mathrm{H}_{2} \mathrm{O}$ (Alfa Aesar (China) Chemical Co., Ltd, $99.0 \%$ ) were mixed and used as precursors and $\gamma-\mathrm{Al}_{2} \mathrm{O}_{3}$ (Sinopharm Chemical Reagent Co., Ltd, 98.0\%) was used as support. After impregnation, the catalysts were placed in the atmosphere statically overnight and then dried in the flowing air at $80{ }^{\circ} \mathrm{C}$ for $12 \mathrm{~h}$ and then calcined at $600{ }^{\circ} \mathrm{C}$ for $2 \mathrm{~h}$. The metal loading is based on the weight ratio between metal and $\gamma-\mathrm{Al}_{2} \mathrm{O}_{3}$.

Characterization. Transmission electron microscope (TEM) images were taken using a JEOL JEM $2100 \mathrm{~F}$ system at an accelerating voltage of $200 \mathrm{kV}$ equipped with a field emission gun. For the catalysts of $0.1 \mathrm{Pt} / \mathrm{Al}_{2} \mathrm{O}_{3}$ and $0.1 \mathrm{Pt} 10 \mathrm{Cu} / \mathrm{Al}_{2} \mathrm{O}_{3}$, the sample was firstly reduced at $600{ }^{\circ} \mathrm{C}$ for $1 \mathrm{~h}$ in a stream of $18 \mathrm{vol} \% \mathrm{H}_{2} / \mathrm{N}_{2}$. Then, the sample powder was dispersed in deionized water by ultrasonic and supported on a copper grid coated with an ultrathin holey carbon film.

The in situ diffuse reflectance infrared Fourier-transform spectroscopy (DRIFTS) experiments were performed on a Thermo Scientific Nicolet IS50 spectrometer, equipped with a Harrick Scientific DRIFTS cell fitted with ZnSe windows and a mercury-cadmium-telluride (MCT) detector cooled by liquid $\mathrm{N}_{2}$. The DRIFTS measurements were carried out for catalysts with fixed amount of $\mathrm{Pt}$ $(0.1 \mathrm{wt} \%)$ and different content of $\mathrm{Cu}$. The fresh and spent catalysts were heated from ambient temperature to $600{ }^{\circ} \mathrm{C}$ at a rate of $10^{\circ} \mathrm{C} \mathrm{min}-1$ and retained at $600{ }^{\circ} \mathrm{C}$ in a flow rate of $50 \mathrm{~mL} \mathrm{~min}^{-1}$ of $20 \mathrm{vol} \% \mathrm{H}_{2} / \mathrm{Ar}$. Then, the catalysts were cooled down to $30^{\circ} \mathrm{C}$ and the backgrounds $\left(8 \mathrm{~cm}^{-1}\right.$ resolution, 64 scans) were collected after Ar purging in a flow rate of $20 \mathrm{~mL} \mathrm{~min}^{-1}$ for at least $1 \mathrm{~h}$. With the addition of a flow of $3 \mathrm{~mL} \mathrm{~min}^{-1}$ of $\mathrm{CO}$, the adsorption of CO molecules on the surface of the catalysts continued for $30 \mathrm{~min}$. After that, the DRIFTS spectra were recorded till no visible change in the absorption band intensities under Ar purging.

High-angle annular dark-field scanning transmission electron microscopy (HAADF-STEM) images were collected using a Titan Cubed Themis G2 300 (FEI) $200 \mathrm{kV}$ aberration-corrected scanning transmission electron microscope (ACSTEM), capable of sub-angstrom resolution at Tianjin University of Technology. For the catalysts of $0.1 \mathrm{Pt} 10 \mathrm{Cu} / \mathrm{Al}_{2} \mathrm{O}_{3}$ and $10 \mathrm{Cu} / \mathrm{Al}_{2} \mathrm{O}_{3}$, the sample was first reduced at $700{ }^{\circ} \mathrm{C}$ for $1 \mathrm{~h}$ in a stream of $18 \mathrm{vol} \% \mathrm{H}_{2} / \mathrm{N}_{2}$. Then, the sample powder was dispersed in deionized water by ultrasonic and deposited on a molybdenum grid coated with an ultrathin holey carbon film.

Pt L3 edge (11.564 keV) XAS spectra were collected at the 10 ID beam line at the Advance Photo Source, Argonne National laboratory. Due to the low $\mathrm{Pt}$ loading, the Pt edge was measured in fluorescence mode. Since $\mathrm{Cu}$ has a fluorescence line near that of $\mathrm{Pt}$ and there is a large loading of $\mathrm{Cu}$, an energy resolved fluorescence spectrometer using a bent crystal laue energy analyzer with soller slits and a Pilatus 100k silicon pixel detector was required to detect from the weak Pt fluorescence signal without saturating the detector with fluorescence form copper. Samples for XAS analysis were ground into a fine powder and pressed into a stainless-steel sample holder. Samples were treated in situ in a custom built reactor ${ }^{64}$ and heated to $550{ }^{\circ} \mathrm{C}$ in $3 \% \mathrm{H}_{2}$ (balance $\mathrm{He}$ ) for $30 \mathrm{~min}$ and then cooled to $100{ }^{\circ} \mathrm{C}$ for collection of spectra. Several spectra were averaged to give the final data used in analysis. There were no noticeable differences in the first and last spectra collected for each sample, demonstrating that the catalyst did not change over the course of measurement. Helium used was passed through a copper trap to remove trace oxygen impurities.

$\mathrm{Cu}-\mathrm{K}$ edge spectra were collected at the 10BM beam line at the Advance Photo Source, Argonne national laboratory. Samples for XAS analysis were ground into a fine powder and pressed into a stainless-steel sample holder. Sample holders were placed in quartz tube reactors equipped with kapton windows and three way valves for gas flow. Transmission mode samples were treated in $3 \% \mathrm{H}_{2}$ (balance $\mathrm{He}$ ) at $550{ }^{\circ} \mathrm{C}$ for $30 \mathrm{~min}$. The gas flow was then switched to pure He for $5 \mathrm{~min}$ to desorb surface hydrogen. The sample was then cooled in helium to room temperature and the reactor atmosphere was isolated using the three way valves.

Data analysis was performed using WinXAS 3.1 software. Phase and amplitude functions for $\mathrm{Pt}-\mathrm{Pt}, \mathrm{Pt}-\mathrm{O}$, and $\mathrm{Cu}-\mathrm{Cu}$ scattering were extracted from experimental references. Pt-Pt and $\mathrm{Cu}-\mathrm{Cu}$ scattering phase and amplitude was extracted from their respective foils ( 12 neighbors at $2.77 \AA$ for platinum, 12 neighbors at 2.56 angstroms for $\mathrm{Cu}$ ). $\mathrm{Pt}-\mathrm{O}$ scattering phase and amplitude was extracted from $\mathrm{Na}_{2} \mathrm{Pt}$ $(\mathrm{OH})_{6}$ (six neighbors at 2.05 angstroms). A phase and amplitude function for $\mathrm{Pt}-\mathrm{Cu}$ scattering was created using FEFF using a single $\mathrm{Pt}-\mathrm{Cu}$ pair with a bond distance of 2.66 angstroms. The amplitude reduction factor, absolute Debye-Waller 
factor and E0 correction for the Pt-Cu scattering pair was taken to be the same as the platinum foil, so that fit values of $\mathrm{E} 0$ and debye-waller factor for $\mathrm{Pt}-\mathrm{Cu}$ scattering are relative to that of platinum foil.

Temperature-programmed experiments were all carried out with a Micromeritics AutoChem 2920 apparatus. For TPO measurements, $100 \mathrm{mg}$ of sample was heated at $300^{\circ} \mathrm{C}$ for $1 \mathrm{~h}$ and cooled down to $80^{\circ} \mathrm{C}$ in flowing $\operatorname{Ar}(30$ $\mathrm{mL} \mathrm{min}-1)$ and then treated in flowing $10 \mathrm{vol} \% \mathrm{O}_{2} / \mathrm{He}\left(20 \mathrm{~mL} \mathrm{~min}^{-1}\right)$ at a rate of $10^{\circ} \mathrm{C} \mathrm{min}^{-1}$ up to $700^{\circ} \mathrm{C}$. The signal of $\mathrm{CO}_{2}$ was recorded by HIDEN QIC-20 mass spectrometer. For TPSR of P-D scrambling, $200 \mathrm{mg}$ of sample was packed in a quartz tube. The sample was first treated by heating at a rate of $10^{\circ} \mathrm{C} \mathrm{min}^{-1}$ up to $600^{\circ} \mathrm{C}$ and maintaining for $1 \mathrm{~h}$ in flowing $\mathrm{D}_{2}$ and then cooled down to $50^{\circ} \mathrm{C}$. After Ar purging for $30 \mathrm{~min}$, the gas was switched to flowing 18 vol\% $\mathrm{C}_{3} \mathrm{H}_{8} / \mathrm{N}_{2}$ and the system was purged for $30 \mathrm{~min}$. Subsequently, the temperature of the sample was raised to $400^{\circ} \mathrm{C}$ at a rate of $5^{\circ} \mathrm{C} \mathrm{min}^{-1}$ and the signals at $\mathrm{m} / z$ of 45,44 , and 4 were monitored by the mass spectrometer.

Turnover frequency (TOF) was calculated as moles of propylene formed per mole of exposed Pt per second:

$$
\mathrm{TOF}=R_{\mathrm{C} 3 \mathrm{H} 6} / D_{\mathrm{Pt}}
$$

where $R_{\mathrm{C} 3 \mathrm{H} 6}$ is the specific activity of propylene formation ( $\mathrm{s}^{-1}$ ) (Supplementary Table 8) and $D_{\mathrm{Pt}}$ is the dispersion of Pt.

Catalytic testing. Catalytic tests were performed in a quartz fixed-bed reactor with $8 \mathrm{~mm}$ inner diameter and $24 \mathrm{~cm}$ length at atmosphere pressure. A volume of 250 $\mathrm{mg}$ of the calcined catalyst with particle size of $20-40$ mesh was packed inside the quartz tubular reactor. The sample was first heated to $600{ }^{\circ} \mathrm{C}$ at a rate of $10^{\circ} \mathrm{C} \mathrm{min}$ ${ }^{-1}$ and retained at $600{ }^{\circ} \mathrm{C}$ for $1 \mathrm{~h}$ in flowing $18 \mathrm{vol} \% \mathrm{H}_{2} / \mathrm{N}_{2}$. Afterward, a mixture of $\mathrm{C}_{3} \mathrm{H}_{8}, \mathrm{H}_{2}$, and $\mathrm{N}_{2}(8: 8: 34 \mathrm{vol} \%)$ was fed at a rate of $50 \mathrm{~mL} \mathrm{~min}^{-1}$. The weight hourly velocity (WHSV) of propane was around $4 \mathrm{~h}^{-1}$. The gas products were analyzed by an online GC (2060) equipped with a flame ionization detector (Chromosorb 102 column) and a thermal conductivity detector $\left(\mathrm{Al}_{2} \mathrm{O}_{3}\right.$ Plot column). The propane conversion and selectivity to propylene were calculated from Eq. (2) and Eq. (3), respectively:

$$
\begin{aligned}
& \mathrm{Con}(\%)=100 \times\left(\left[F_{\mathrm{C} 3 \mathrm{H} 8}\right]_{\text {inlet }}-\left[F_{\mathrm{C} 3 \mathrm{H} 8}\right]_{\text {outlet }}\right) /\left[F_{\mathrm{C} 3 \mathrm{H} 8}\right]_{\text {inlet }} . \\
& \operatorname{Sel}(\%)=100 \times\left[F_{\mathrm{C} 3 \mathrm{H} 6}\right]_{\text {outlet }} /\left(\left[F_{\mathrm{C} 3 \mathrm{H} 8}\right]_{\text {inlet }}-\left[F_{\mathrm{C} 3 \mathrm{H} 8}\right]_{\text {outlet }}\right) .
\end{aligned}
$$

Where $F_{\mathrm{C} 3 \mathrm{H} 8}$ and $F_{\mathrm{C} 3 \mathrm{H} 6}$ means mole flow rate of propane and propylene. A firstorder deactivation model was used to evaluate the catalyst stability:

$$
k_{\mathrm{d}}=\left(\ln \left[\left(1-X_{\text {final }}\right) / X_{\text {final }}\right]-\ln \left[\left(1-X_{\text {initial }}\right) / X_{\text {intial }}\right]\right) / t
$$

where $X_{\text {intial }}$ and $X_{\text {final }}$, respectively, represent the conversion measured at the initial and final period of an experiment, and $t$ represents the reaction time (h), $k_{\mathrm{d}}$ is the deactivation rate constant $\left(\mathrm{h}^{-1}\right)$. High $k_{\mathrm{d}}$ value means rapid deactivation, that is, low stability. The mean catalyst life $(\tau)$ represents the time required for rates to decrease by $\mathrm{e}^{-1}$, and is estimated with the reciprocal of the deactivation rate constants.

\section{Data availability}

The data that support the findings of this study are available from the corresponding author upon request.

Received: 19 June 2018 Accepted: 8 October 2018

Published online: 26 October 2018

\section{References}

1. Medford, A. J. et al. From the sabatier principle to a predictive theory of transition-metal heterogeneous catalysis. J. Catal. 328, 36-42 (2015).

2. Khorshidi, A., Violet, J., Hashemi, J. \& Peterson, A. A. How strain can break the scaling relations of catalysis. Nat. Catal. 1, 263-268 (2018).

3. Mehta, P. et al. Overcoming ammonia synthesis scaling relations with plasmaenabled catalysis. Nat. Catal. 1, 269-275 (2018).

4. Studt, F. et al. Identification of non-precious metal alloy catalysts for selective hydrogenation of acetylene. Science 320, 1320-1322 (2008).

5. Pham, H. N., Sattler, J. J. H. B., Weckhuysen, B. M. \& Datye, A. K. Role of Sn in the regeneration of $\mathrm{Pt} / \mathrm{\gamma}-\mathrm{Al}_{2} \mathrm{O}_{3}$ light alkane dehydrogenation catalysts. ACS Catal. 6, 2257-2264 (2016).

6. Silvestre-Albero, J., Serrano-Ruiz, J. C., Sepúlveda-Escribano, A. \& RodríguezReinoso, F. Zn-modified MCM-41 as support for Pt catalysts. Appl. Catal. A. Gen. 351, 16-23 (2008).

7. Sun, P., Siddiqi, G., Chi, M. \& Bell, A. T. Synthesis and characterization of a new catalyst $\mathrm{Pt} / \mathrm{Mg}(\mathrm{Ga})(\mathrm{Al}) \mathrm{O}$ for alkane dehydrogenation. J. Catal. 274, 192-199 (2010).
8. Sun, P., Siddiqi, G., Vining, W. C., Chi, M. \& Bell, A. T. Novel Pt/Mg(In)(Al)O catalysts for ethane and propane dehydrogenation. J. Catal. 282, 165-174 (2011).

9. Ballarini, A. D., de Miguel, S. R., Castro, A. A. \& Scelza, O. A. N-decane dehydrogenation on Pt, PtSn and PtGe supported on spinels prepared by different methods of synthesis. Appl. Catal. A. Gen. 467, 235-245 (2013).

10. Han, Z. et al. Propane dehydrogenation over Pt-Cu bimetallic catalysts: the nature of coke deposition and the role of copper. Nanoscale 6, 10000-10008 (2014).

11. Zha, S. et al. Identification of Pt-based catalysts for propane dehydrogenation via a probability analysis. Chem. Sci. 9, 3925-3931 (2018).

12. Li, Y. \& Sun, Q. Recent advances in breaking scaling relations for effective electrochemical conversion of $\mathrm{CO}_{2}$. Adv. En. Mat. 6, 1600463 (2016).

13. Wang, A., Li, J. \& Zhang, T. Heterogeneous single-atom catalysis. Nat. Rev. Chem. 2, 65-81 (2018).

14. Andrew, J. T. et al. An atomic-scale view of single-site Pt catalysis for low temperature CO oxidation. Nat. Catal. 1, 192-198 (2018).

15. Nie, L. et al. Activation of surface lattice oxygen in single-atom $\mathrm{Pt} / \mathrm{CeO}_{2}$ for low-temperature CO oxidation. Science 358, 1419-1423 (2017).

16. Lin, J. et al. Remarkable performance of $\mathrm{Ir}_{1} / \mathrm{FeO}_{\mathrm{x}}$ single-atom catalyst in water gas shift reaction. J. Am. Chem. Soc. 135, 15314-15317 (2013).

17. Yang, M. et al. Catalytically active Au-O- $(\mathrm{OH})_{\mathrm{x}}$ species stabilized by alkali ions on zeolites and mesoporous oxides. Science 346, 1498-1501 (2014).

18. Yang, M. et al. A common single-site $\mathrm{Pt}(\mathrm{II})-\mathrm{O}--(\mathrm{OH})_{\mathrm{x}}$ species stabilized by sodium on "active" and "inert" supports catalyzes the water-gas shift reaction. J. Am. Chem. Soc. 137, 3470-3473 (2015).

19. Gu, X.-K. et al. Supported single $\mathrm{Pt}_{1} / \mathrm{Au}_{1}$ atoms for methanol steam reforming. ACS Catal. 4, 3886-3890 (2014).

20. Lin, L. et al. Low-temperature hydrogen production from water and methanol using Pt/a-MoC catalysts. Nature 544, 80-83 (2017).

21. Fei, H. et al. Atomic cobalt on nitrogen-doped graphene for hydrogen generation. Nat. Commun. 6, 8668 (2015).

22. Cheng, N. et al. Platinum single-atom and cluster catalysis of the hydrogen evolution reaction. Nat. Commun. 7, 13638 (2016).

23. Deng, J. et al. Triggering the electrocatalytic hydrogen evolution activity of the inert two-dimensional $\mathrm{MoS}_{2}$ surface via single-atom metal doping. Energy \& Environ. Sci. 8, 1594-1601 (2015).

24. Wei, $\mathrm{H}$. et al. $\mathrm{FeO}_{\mathrm{x}}$-supported platinum single-atom and pseudo-single-atom catalysts for chemoselective hydrogenation of functionalized nitroarenes. Nat. Commun. 5, 5634 (2014).

25. Wei, H. et al. Remarkable effect of alkalis on the chemoselective hydrogenation of functionalized nitroarenes over high-loading $\mathrm{Pt} / \mathrm{FeO}_{\mathrm{x}}$ catalysts. Chem. Sci. 8, 5126-5131 (2017).

26. Kyriakou, G. et al. Isolated metal atom geometries as a strategy for selective heterogeneous hydrogenations. Science 335, 1209-1212 (2012).

27. Yan, H. et al. Single-atom $\mathrm{Pd}_{1} /$ graphene catalyst achieved by atomic layer deposition: Remarkable performance in selective hydrogenation of 1,3butadiene. J. Am. Chem. Soc. 137, 10484-10487 (2015).

28. Vilé, G. et al. A stable single-site palladium catalyst for hydrogenations. Angew. Chem. Int. Ed. 54, 11265-11269 (2015).

29. Lucci, F. R. et al. Selective hydrogenation of 1,3-butadiene on platinum-copper alloys at the single-atom limit. Nat. Commun. 6, 8550 (2015).

30. Matsubu, J. C., Yang, V. N. \& Christopher, P. Isolated metal active site concentration and stability control catalytic $\mathrm{CO}_{2}$ reduction selectivity. J. Am. Chem. Soc. 137, 3076-3084 (2015).

31. Kwak, J. H., Kovarik, L. \& Szanyi, J. Heterogeneous catalysis on atomically dispersed supported metals: $\mathrm{CO}_{2}$ reduction on multifunctional pd catalysts. ACS Catal. 3, 2094-2100 (2013).

32. Li, S. et al. Tuning the selectivity of catalytic carbon dioxide hydrogenation over iridium/cerium oxide catalysts with a strong metal-support interaction. Angew. Chem. Int. Ed. 56, 10761-10765 (2017).

33. Schweitzer, N. M. et al. Propylene hydrogenation and propane dehydrogenation by a single-site $\mathrm{Zn}^{2+}$ on silica catalyst. ACS Catal. 4, 1091-1098 (2014).

34. $\mathrm{Hu}, \mathrm{B}$. et al. Selective propane dehydrogenation with single-site $\mathrm{Co}$ (II) on $\mathrm{SiO}_{2}$ by a non-redox mechanism. J. Catal. 322, 24-37 (2015).

35. Zhang, G., Yang, C. \& Miller, J. T. Tetrahedral nickel(II) phosphosilicate single-site selective propane dehydrogenation catalyst. ChemCatChem 10, 961-964 (2018)

36. Searles, K., Siddiqi, G., Safonova, O. V. \& Copéret, C. Silica-supported isolated gallium sites as highly active, selective and stable propane dehydrogenation catalysts. Chem. Sci. 8, 2661-2666 (2017).

37. Marcinkowski, M. D. et al. $\mathrm{Pt} / \mathrm{Cu}$ single-atom alloys as coke-resistant catalysts for efficient C-H activation. Nat. Chem. 10, 325-332 (2018).

38. Li, Z. et al. Atomically dispersed $\mathrm{Pt}$ on the surface of Ni particle - synthesis and catalytic function in hydrogen generation from aqueous ammonia borane. ACS Catal. 7, 6762-6769 (2017).

39. Shan, J. et al. Water co-catalyzed selective dehydrogenation of methanol to formaldehyde and hydrogen. Surf. Sci. 650, 121-129 (2016). 
40. Zhao, Z.-J., Chiu, C.-C. \& Gong, J. Molecular understandings on the activation of light hydrocarbons over heterogeneous catalysts. Chem. Sci. 6, 4403-4425 (2015).

41. Sattler, J. J., Ruiz-Martinez, J., Santillan-Jimenez, E. \& Weckhuysen, B. M. Catalytic dehydrogenation of light alkanes on metals and metal oxides. Chem. Rev. 114, 10613-10653 (2014).

42. Xiong, $\mathrm{H}$. et al. Thermally stable and regenerable platinum-tin clusters for propane dehydrogenation prepared by atom trapping on ceria. Angew. Chem. Int. Ed. 56, 8986-8991 (2017).

43. Liu, J. Catalysis by supported single metal atoms. ACS Catal. 7, 34-59 (2017).

44. Strasser, P. et al. Lattice-strain control of the activity in dealloyed core-shell fuel cell catalysts. Nat. Chem. 2, 454-460 (2010).

45. Qiao, B. et al. Single-atom catalysis of $\mathrm{CO}$ oxidation using $\mathrm{Pt}_{1} / \mathrm{FeO}_{\mathrm{x}}$. Nat. Chem. 3, 634-641 (2011)

46. Liu, J. et al. Tackling CO poisoning with single-atom alloy catalysts. J. Am. Chem. Soc. 138, 6396-6399 (2016).

47. Moses-DeBusk, M. et al. CO oxidation on supported single Pt atoms: experimental and ab initio density functional studies of $\mathrm{CO}$ interaction with $\mathrm{Pt}$ atom on $\theta-\mathrm{Al}_{2} \mathrm{O}_{3}(010)$ surface. J. Am. Chem. Soc. 135, 12634-12645 (2013).

48. Kappers, M. J. \& van der Maas, J. H. Correlation between CO frequency and Pt coordination number. A drift study on supported Pt catalysts. Catal. Lett. 10, 365-373 (1991).

49. Jones, J. et al. Thermally stable single-atom platinum-on-ceria catalysts via atom trapping. Science 353, 150-154 (2016).

50. DeRita, L. et al. Catalyst architecture for stable single atom dispersion enables site-specific spectroscopic and reactivity measurements of $\mathrm{CO}$ adsorbed to $\mathrm{Pt}$ atoms, oxidized Pt clusters, and metallic Pt clusters on $\mathrm{TiO}_{2}$. J. Am. Chem. Soc. 139, 14150-14165 (2017)

51. Zhang, $\mathrm{Z}$. et al. Thermally stable single atom $\mathrm{Pt} / \mathrm{m}-\mathrm{Al}_{2} \mathrm{O}_{3}$ for selective hydrogenation and CO oxidation. Nat. Commun. 8, 16100 (2017).

52. Peterson, E. J. et al. Low-temperature carbon monoxide oxidation catalysed by regenerable atomically dispersed palladium on alumina. Nat. Commun. 5, 4885 (2014).

53. Zhu, J. et al. Size-dependent reaction mechanism and kinetics for propane dehydrogenation over Pt catalysts. ACS Catal. 5, 6310-6319 (2015).

54. Liu, G. et al. Platinum-modified $\mathrm{ZnO} / \mathrm{Al}_{2} \mathrm{O}_{3}$ for propane dehydrogenation: minimized platinum usage and improved catalytic stability. ACS Catal. 6, 2158-2162 (2016).

55. Shi, $\mathrm{L}$. et al. $\mathrm{Al}_{2} \mathrm{O}_{3}$ nanosheets rich in pentacoordinate $\mathrm{Al}(3+)$ ions stabilize Pt-Sn clusters for propane dehydrogenation. Angew. Chem. Int. Ed. 54, 13994-13998 (2015).

56. $\mathrm{Li}, \mathrm{Q}$. et al. Coke formation on $\mathrm{Pt}-\mathrm{Sn} / \mathrm{Al}_{2} \mathrm{O}_{3}$ catalyst in propane dehydrogenation: coke characterization and kinetic study. Top. Catal. 54, 888 (2011).

57. Redekop, E. A. et al. Early stages in the formation and burning of graphene on a $\mathrm{Pt} / \mathrm{Mg}(\mathrm{Al}) \mathrm{O}_{\mathrm{x}}$ dehydrogenation catalyst: a temperature- and time-resolved study. J. Catal. 344, 482-495 (2016).

58. Kresse, G. \& Furthmüller, J. Efficient iterative schemes for ab initio total-energy calculations using a plane-wave basis set. Phys. Rev. B. 54, 11169-11186 (1996).

59. Mortensen, J. J. et al. Bayesian error estimation in density-functional theory. Phys. Rev. Lett. 95, 216401 (2005).

60. Wellendorff, J. et al. Density functionals for surface science: exchangecorrelation model development with Bayesian error estimation. Phys. Rev. B. 85, 235149 (2012).

61. Blöchl, P. E. Projector augmented-wave method. Phys. Rev. B. 50, 17953-17979 (1994).

62. de Montigny, M. \& Marleau, L. Production of leptoquark scalars in hadron colliders. Phys. Rev. D. 40, 2869-2874 (1989).
63. Monkhorst, H. J. \& Pack, J. D. Special points for Brillouin-zone integrations. Phys. Rev. B. 13, 5188-5192 (1976).

64. Bolin, T. B. et al. In situ intermediate-energy X-ray catalysis research at the advanced photon source beamline 9-bm. Catal. Today 205, 141-147 (2013).

\section{Acknowledgements}

The authors thank the National Science Foundation of China (21525626, 21506149, 91645106, U1663224) and the Program of Introducing Talents of Discipline to Universities (No. B06006) for financial support. S.C.P. and J.T.M. are supported in part by the National Science Foundation under Coopperative Agreement No. EEC-1647722. Use of the Advanced Photo Source is supported by the U.S. Department of Energy, Office of Basic Energy Sciences, under contract no. DEAC02-06CH11357. MRCAT operations, beamline 10-BM, are supported by the Department of Energy and the MRCAT member institutions. Z.L is supported by the BioEnergy Technolgies Office, Office of Energy Efficiency and Renewable Energy, U.S. Department of Energy.

\section{Author contributions}

J.G. conceived and coordinated the research. Z.Z., S.Z. and L.L. screened Pt/Cu(111) SAA catalyst by DFT. G.S. contributed to catalyst synthesis and catalytic experiments. G.S. and S.C. performed in situ DRIFTS experiments, TPSR and long-term stability experiments K.Z. and J.L. collected and analysed the AC-HAADF-STEM data. S.C.P, A.J.K. and J.T.M performed the EXAFS measurements and analysed the data. Z.Z., G.S., R.M., Z.L. and J.G. wrote the manuscript. All the authors participated in discussions of the research.

\section{Additional information}

Supplementary Information accompanies this paper at https://doi.org/10.1038/s41467018-06967-8.

Competing interests: The authors declare no competing interests.

Reprints and permission information is available online at http://npg.nature.com/ reprintsandpermissions/

Publisher's note: Springer Nature remains neutral with regard to jurisdictional claims in published maps and institutional affiliations.

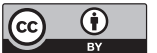

Open Access This article is licensed under a Creative Commons Attribution 4.0 International License, which permits use, sharing, adaptation, distribution and reproduction in any medium or format, as long as you give appropriate credit to the original author(s) and the source, provide a link to the Creative Commons license, and indicate if changes were made. The images or other third party material in this article are included in the article's Creative Commons license, unless indicated otherwise in a credit line to the material. If material is not included in the article's Creative Commons license and your intended use is not permitted by statutory regulation or exceeds the permitted use, you will need to obtain permission directly from the copyright holder. To view a copy of this license, visit http://creativecommons.org/ licenses/by/4.0/.

(c) The Author(s) 2018 